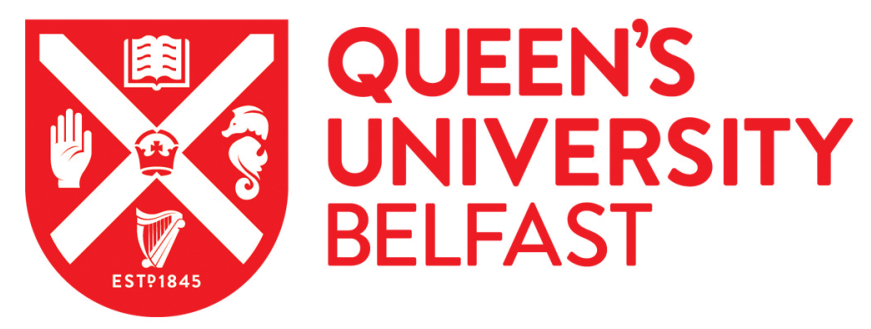

\title{
Workplace unionism under decentralised bargaining in France: A case study of the CGT in the car industry
}

Reaney, R., \& Cullinane, N. (2017). Workplace unionism under decentralised bargaining in France: A case study of the CGT in the car industry. Industrial Relations Journal, 48(5-6), 403. https://doi.org/10.1111/irj.12191

Published in:

Industrial Relations Journal

Document Version:

Peer reviewed version

Queen's University Belfast - Research Portal:

Link to publication record in Queen's University Belfast Research Portal

Publisher rights

(C) 2017 Brian Towers (BRITOW) and John Wiley \& Sons Ltd.

This work is made available online in accordance with the publisher's policies. Please refer to any applicable terms of use of the publisher

\section{General rights}

Copyright for the publications made accessible via the Queen's University Belfast Research Portal is retained by the author(s) and / or other copyright owners and it is a condition of accessing these publications that users recognise and abide by the legal requirements associated with these rights.

Take down policy

The Research Portal is Queen's institutional repository that provides access to Queen's research output. Every effort has been made to ensure that content in the Research Portal does not infringe any person's rights, or applicable UK laws. If you discover content in the Research Portal that you believe breaches copyright or violates any law, please contact openaccess@qub.ac.uk. 
Workplace unionism under decentralised bargaining in France: A case study of the CGT in the car industry

ACCEPTED FOR PUBLICATION 23 August 2017 


\begin{abstract}
Considering recent theoretical accounts on the trajectory of French unionism under localised bargaining, this article examines potential consequences for the country's traditionally largest radical union, Confédération Générale du Travail (CGT). Deploying a case study of CGT at PSA Peugeot Citroën and Renault in the years since the 2008 automotive crisis, the article observes a persistent pattern of militant opposition within company and plant union sections. Company bargaining structure, inter-union reformist collaboration and electoral considerations are identified as workplace mechanisms reinforcing CGT actions at this level.
\end{abstract}




\section{Introduction}

The increasing substitution of sectoral agreements for those struck at company and plant is an established European trend. In France, collective bargaining has historically been conducted at sector level with central agreements concluded between employer associations and unions. Decentralisation of bargaining to the company started from the early 1980 s, although the principle of favourability forbade company agreements from providing less favourable terms than those agreed at sector. This principle has been significantly diluted in recent reforms which provide greater autonomy and flexibility in the conclusion of company level agreements (Marginson, 2015). Such trends have been accompanied by reforms in union representativeness whereby electoral audiences at workplace determine bargaining capacity, rather than presumptions of national representativeness. Recent literature on French industrial relations hints at diverging trajectories for trade unionism in this context of decentralisation. In one strand, greater decentralisation is said to reinforce pre-existing weaknesses in the unions (Howell, 2009). Exposed to firms' competitive pressures, workplace unions risk succumbing to a subordinated compliance in ensuring plant viability. However, an alternative interpretation implies that such risks are overstated. Drawing on a macro-cultural account of French industrial relations, it proposes a 'permissive ideational environment' that continues to legitimise and sustain radical action even amid crisis (Parsons, 2013a; see also Milner, 2002; Milner and Mathers, 2013; Mathers, 2017).

Given diverging theoretical pathways, the article examines the trajectory of France's traditionally largest radical union, Confédération Générale du Travail (CGT) at 
company and plant level where competitiveness bargaining occurs to preserve plant viability. While scholarship has been conscious of a CGT shift from militancy at the confederal centre (Giraud, 2015), literature suggests that the confederation's response to bargaining at devolved levels is not well understood. It is difficult to infer workplace behaviour from national confederal trends given traditions of union autonomy at sector and company (Thomas, 2016). To contribute to knowledge and understanding, the article focuses on CGT company and plant sections syndicales (trade union sections), considering how firm competitive pressures impact radical unions' workplace bargaining, and whether responses pull in the direction of greater cooperation or if more paradigmatic militant stances prevail. Specifically, the article uses a case study examining CGT in the French automotive industry at PSA PeugeotCitroën (PSA) and Renault across 12 plants over several years after the automotive crisis of 2008. The article shows CGT adopting a pattern of militant opposition towards employers despite sustained job loss and threats to plant viability. We propose several institutional influences encouraging such outcomes. In what follows, the article develops the study's rationale, the research design and findings. The discussion of the case and its potential for more generalised application concludes the piece.

\section{Context: Workplace bargaining and radical unionism in France}

The progressive shift from sectoral to company level bargaining in France has been shaped by concerns over employer competitiveness, an issue with added significance in a country where deindustrialisation is pronounced. French manufacturing has seen its share in value-added terms drop to one of the lowest in the Eurozone behind Italy and Spain (National Institute for Statistics and Economic Studies, 2014). Since 2007, an estimated 345,000 manufacturing jobs have been lost, with foreign competition 
identified as a primary cause (ibid.). Competition in the global market has eroded the competitiveness of French businesses, both in exports and domestically.

In this context, the state has sought to encourage greater workplace bargaining to aid employer flexibility and bolster competitiveness. Where the 'favourability principle' once forbade company agreements from providing inferior terms to those agreed at sector, 'derogations' now weaken this practice. The Fillon Law (2004), Social Democracy and Working Time (2008), Employment Securitisation (2013) and the Macron Law (2015) expand the range of derogations available. For example, company pacts can now provide for less favourable pay that sectoral rates in exchange for job security where employers face economic difficulties and work hours can now be fixed independently of industry agreements. In supporting company level bargaining, the structure of union representation has been reorganised. Since 2008, delegates appointed for negotiations have been selected according to quadrennial elections rather than affiliation to one of the confederations that had been presumed to be nationally representative (Laulom, 2012). Elections to plant comités d'entreprise (CE) ${ }^{1}$ are now the test of representativeness for negotiation rights, with unions needing $10 \%$ support to be representative and $30 \%$ to sign agreements, although the latter has been revised under the 2016 El-Khomri Law to 50\%. The 2008 reforms empowered unions commanding $50 \%$ to oppose negotiated agreements, since modified under El-Khomri so that unions with $30 \%$ may only refer objections to an employee referendum. Support from workplace electoral audiences thus determines union capacity to partake in and influence bargaining.

\footnotetext{
${ }^{1}$ Enterprise committees, statutory information and consultation bodies, operate at workplace level. Their equivalent at company level are termed Comités Centraux de l'Entreprise (CCE).
} 
In this context of decentralisation, whither French unionism? Traditions of sectoral bargaining have produced a legacy inhospitable to workplace unionism, exemplified by France's low union density. Consequently, some theorise that decentralisation aggravates pre-existing union weaknesses in the workplace, leading to isolated worker collectivities (Pernot, 2010). While the growing incidence of non-union bodies is one conduit for this, "severely weakened unions" (Howell, 2009: 236) is another. This reflects notions that firm-specific competitive pressures encourage workplace unions to develop a 'plant egoism', acting in ways that depart from confederal lines (Streeck, 1984). As Rogers and Streeck (1995: 12) theorise, concessionary pressures on plant unionism raise implications for radical confederations particularly:

For militant unions engaged in political class struggle, the enterprise is a sphere of potential wildcat cooperation with the employer: workers acting on their narrow interest in the health and profitability of "their" firm and disregarding the interests of the working class as a whole. Industrial unions' typical fear of workplace-based particularism opened the possibility, and often indeed produced the reality, of an unlikely compromise.

A domestication of radical unionism is implied with union sections succumbing to a "bias towards cooperation...centred around the needs of the firm" (Howell, 1992: 261), becoming "functionally indistinguishable from enterprise unions" (Howell, 2009: 236; c.f. Goyer and Hancké, 2004). A 'micro-corporatist' enterprise consciousness thus prevails, whereby unions internalise employers' competitiveness agenda (Levesque and Murray, 2005: 506). This is likely to be pronounced under crisis conditions where plant viability and jobs are at stake.

Yet, counselling against union incorporation is a theoretical assessment highlighting radical unions' inelasticity to change (Parson, 2013a). Drawing on macro-cultural 
traditions of the French system, this analysis emphasises a "permissive ideational environment" (ibid. 303) for radical action even in conditions of economic crisis. The combined legacies of employer unilateralism, union syndicalism and a dirigiste state willing to moderate the market and shore up the confederations, encourage a mix of militancy and protest for workplace culture (c.f. Milner, 2002). Allied to widespread cynicism in France about globalisation's merits, an environment exists in which militant contestation retains a high degree of legitimacy (see also Mathers, 2017). Coercive market forces do not simply disembowel ideological orientations of radical unions, as traditions persist and mediate crisis pressures. Under this scenario, localised bargaining will continue to see evidence of union contestation.

Divergent trajectories within the above literature raise implications for radical confederations, who remain an established feature of France's institutional framework. Notable here is CGT with a reported 710,000 members. Historically CGT strategy has prioritised political mobilisation at national level (Upchurch et al. 2009). Denouncing and refusing to sign agreements have been its hallmark, condemning rival unions that do sign as engaging in class compromise. Yet contemporary accounts emphasise a shift from a "union of refusal" to a "unionism of proposals and negotiations", although the nature and extent of this transformation is unclear (Andolfatto, 2007). Accounts emphasise declining membership and reduced Parti Communiste Français (PCF) influence over the confederation as encouraging reform (Connolly, 2014). More recently, the union has been overtaken by Confédération Française Démocratique du Travail (CFDT) as France's most representative union nationally (Ministère du Travail, 2017), inducing a further bout of internal 
reassessment within $\mathrm{CGT}^{2}$. Faced with new challenges, a partial move to the centreleft and closer relations with Parti Socialiste (PS) have been encouraged including electoral support for François Hollande (Parsons, 2015). There are also accounts of greater CGT willingness to sign agreements (Labbé and Nezosi, 2007; Milner and Mathers, 2013) although this may depend on whether these are distributive or integrative in character and the level at which they occur (national, sectoral or workplace). For some scholars, CGT retains a reputation as a "systematically belligerent ex-communist" union (Clegg and van Wujnbergen, 2011) relative to the reformist bloc comprising France's fractious confederal scene ${ }^{3}$. Negotiated reform is characterised as difficult given "CGT concerns not to cede that which has been gained through struggle" (Parsons, 2013b: 202). Yet many accounts' focus on national developments may not reflect nuances within a union known for "organised anarchy" and workplace autonomy (Thomas, 2016: 33). Milner (2012) refers to internal tensions over a perceived reformist drift at national level with grassroots unease about any collaboration with CFDT. As recently as 2013, CGT conferences report grassroots resolve to "return to the 'class struggle', with protests to emphasise their discontent" (Tissandier, 2013).

\footnotetext{
${ }^{2}$ See 'La CFDT devance la CGT et devient le premier syndicat de France au niveau national', Le Monde $31^{\text {st }}$ March, 2017

${ }^{3}$ Other radical confederations include the smaller Solidaires Unitaires Démocratiques (SUD)(a leftist split from CFDT); broadly reformist confederations include CFDT (social democratic with leftist/rightist factions), Confédération Française de l'Encadrement-Confédération Générale des Cadres (CFE-CGC) (a managerial union), Confédération Française des Travailleurs Chrétiens CFTC (Christian democratic), Force Ouvrière (FO)(originally anti-communist, economistic in focus) and Union Nationale des Syndicats Autonomes (UNSA)(a confederation of autonomous unions, primarily public sector based).
} 
3. Analytical Framework: Trade union strategy under workplace bargaining Given the uncertainty over how exposure to company level competitive pressures might affect radical unions' workplace bargaining, further consideration is merited. Existing accounts of union strategy can be deployed to frame such analysis. Examining how unions survive where "their world is one of decentralised bargaining with and within firms", Boxall and Haynes (1997: 568$)$ theorise that unions face several strategic choices in ensuring continued effectiveness as organisations. Unions exercise choice insofar as deciding to do one thing implies deciding not to do the other, with choices being strategic insofar as they influence organisational viability. For example, Blyton et al. (2001) demonstrate that in responding to restructuring threats in the aviation industry, unions chose different strategies of conflict and cooperation to protect workers' interests. Some unions pursued adversarial industrial action as an effective response to airline restructuring, while others secured partnerships which shifted restructuring towards quality enhancement and the offering of concessions in exchange for greater influence over management decisions. Effective choices for Boxall and Haynes (1997) require that unions select actions meeting not only the needs of their support base, but which also compel employers to shift their behaviour. Choices are ineffectual, not only where employer positions remain unmoved by union action, but also where unions misjudge the mood of workers and become detached from their support. A risk of 'strategic drift' ensues (Boxall, 2008: 210), with unions becoming disconnected from the challenges presented by their environments, potentially eroding their organisational viability. 
In specifying the kind of strategic choices unions might make in response to competitive pressures at firm level, Bacon and Blyton (2004) offer guidance. They conceptualise union choices as combining ideological 'orientation' of militancy and moderation with 'actions' of conflict and cooperation. Combined, this creates what might be termed four strategic choices: militant-conflict (termed 'militant opposition'), militant-cooperation (termed 'militant engagement'), moderateconflict (termed 'moderate opposition') and moderate-cooperation (termed 'cooperative engagement') (p. 752-754). Militant opposition is a refusal to cooperate with restructuring and protective of the status quo (p. 753). Concluding an agreement in this scenario is unlikely unless the union imposes a 'win' or is coerced into unwilling submission through lockout or strike defeat. In light of the previous discussion, such a pattern would align with traditional CGT postures. However, militants may calculate that opposition is self-defeating where employment loss occurs, or is likely. They may therefore move to problem-solving bargaining to preserve jobs, that is, militant engagement. Here militants bargain with management, cooperating on specific issues and trade-offs where interests coincide (p. 754). However, bargaining relations remain adversarial in this scenario. Next, moderate opposition aligns to classic 'bread and butter' unionism. Here the unions seek to bargain in good faith, but will intermittently adopt uncooperative positions in the bargaining process, where the employer seek "too much 'give' from unions" (p. 753). Unlike militants, moderate unionists will prefer to avoid strike action and cut a 'sellable deal' at the negotiating table. In cooperative engagement, moderate unionists embrace a partnership approach, management are seen to 'play fair' and integrative bargaining is expected as routine (p. 753). Strikes are eschewed as risking plant viability and employer goodwill. 
These different patterns can be used to map an assessment of how radical unions choose to respond to cases of workplace bargaining where employers seek greater competitiveness in exchange for plant viability. Following from the diverging theoretical concerns outlined above and using CGT as a radical exemplar, do localised responses align with their 'paradigmatic' choice of militant opposition or are alternative choices being made? What explains such choices and what implications can be drawn for understanding the choices radical unions face under decentralised bargaining in France generally?

\section{Research Design}

To address the above, a case study is presented drawing on eight years of evidence from company and plant level analysis of CGT sections in PSA and Renault. The case commends itself for several reasons. CGT is the largest union, on representative criteria, in the metalworking industry, forming CGT-Fédération des Travailleurs de la Métallurgie (CGT-FTM) ${ }^{4}$. It has traditionally commanded the largest support in PSA CCE (until 2015) and Renault CCE (until 2011). The auto sector, and PSA and Renault particularly, are also appropriate as the industry has been subject to significant job losses in the aftermath of the 2008 crisis with employers seeking greater competitiveness to secure plant viability.

Indeed, the industry is at the centre of a national debate around relocation as a costcutting business strategy. Automotive manufacturing fell by $40 \%$ between 2005 and 2011. In total, 1.7 million vehicles (of the 3.6 million PSA and Renault produced) were manufactured in France in 2011 against 2.8 million in 2005. The auto sector employed

\footnotetext{
${ }^{4}$ CGT-FTM membership is reported as 65,000
} 
321,000 people in 2000 , dropping to 220,000 in 2010 , while automotive manufacturers now employ 137,000 workers (2016), compared with 187,000 ten years previous. PSA and Renault have accumulated 30,000 combined job losses across France since 2008. Despite status as 'national champions', commanding $65 \%$ of direct employment in the sector, only $40 \%$ of PSA's workforce and $38 \%$ of Renault's are employed nationally. Since the 1990s, both companies have shifted resources from France, favouring new plants abroad. Complementing this trend is the outsourcing of 'noncore' production to suppliers, producing a smaller workforce where production workers have declined relative to professional/technical staff in both firms. In France, $49 \%$ of all PSA employees are production workers, compared with only $30 \%$ in Renault. In both firms, support for CFE-CGC has grown.

For this article, CGT sections' orientation and action are evidenced in the context of the background, negotiation and transposition of competitiveness agreements at PSA and Renault. The period of study is 2008-2015, with emphasis on the 2012-2013 period of negotiated competitiveness agreements. Developments are studied at company level and at nine assembly and three powertrain sites, where redundancies were widespread and plant closure was regularly threatened (Table 1). Evidence was gathered via archival documentation, interviews and observational fieldwork (Table 2).

Table 1

Table 2 
Questions of reliability and validity were addressed during fieldwork. Reliability of evidence was corroborated by triangulating across different evidence sources and different unions on the same issues. Regarding validity of the evidence, Strauss's (1987) coding process was followed. Identification of codes was based on patterns laid out in Section 2.

\section{Findings}

\section{PSA Company Level}

The 2008 crisis prompted substantial employment restructuring at PSA. Initiated with 3,500 redundancies, pay was frozen (2008-2010), followed by a below-inflation increase (2010-2011) and pay pauses (2012-2015). In 2012 PSA announced 8,000 redundancies, with the Aulnay plant, employing 3,600 workers, identified for closure. Rennes and Sevelnord also risked shutdown with these plans emerging after a CGT press conference presented leaked executive memos to the media, revealing production transfer to either "Turkey, Morocco or Eastern Europe". Announcement of Aulnay's closure produced an alliance involving company and plant sections of CFECGC, CFTC, FO and GSEA to develop a social plan for redundancy and redeployment. CGT remained independent of the alliance, as did CFDT. Table 3 identifies the representative unions at PSA in this period.

\section{Table 3}

Rejecting site closure in principle, CGT proposed saving Aulnay by more egalitarian inter-plant volume distributions, reducing executive remuneration and redirecting dividends and former executive pensions toward financing suspended hybrid projects. The closure announcement was followed by CGT Aulnay organising a four-month 
strike involving 300 workers at the site. The strike evidenced flying pickets, reported violence and plant sabotage by CGT activists. CFDT Aulnay initially participated before CFDT centre ordered a return to work. In response, the reformist alliance organised a campaign 'Come Together to Save PSA!', claiming "Trotskyite infiltration" of CGT Aulnay and CGT intimidation of non-strikers. During the strike, the alliance further requested, and management obliged, to bring Aulnay's closure forward from 2014 to late 2013:

The situation at Aulnay can no longer guarantee employees' physical and psychological security. Already heavily affected by the planned closure of their site, these employees should not have to suffer the misconduct, intimidation and harassment of a few troublemakers. Given the circumstances and risks to staff, for the benefit of employees we request the immediate implementation of voluntary redeployment measures under the social plan.

CFE-CGC, CFTC, FO, GSEA CCE Motion

Given sufficient representativeness, a social plan was concluded in March 2013 between PSA and the alliance, with CFDT PSA delegate support. CGT refused to sign, maintaining the strike for a further month before returning to work in exchange for enabling strikers, fired for alleged misconduct, to avail of redundancy and redeployment terms.

Parallel to Aulnay, the future of the Sevelnord plant was under review. Output had declined by approximately $50 \%$ in the four years after 2008 and Fiat terminated its purchasing contract at the site in 2012. A transfer of models to Spain was proposed unless investment and labour concessions were secured. In the interim, a Toyota investment partnership for Sevelnord was obtained, albeit with PSA insisting it hinged on pay moderation and flexibility concessions in return. While CFE-CGC, FO and GSEA entered negotiations, CGT refused, calling for an independent assessment of 
Sevelnord's finances. CGT maintained that Toyota's investment was not contingent on concessions and simply amounted to PSA opportunism. An independent assessment, potentially delaying negotiations by several months, required support from other unions as CGT lacked representative authority to secure a review alone. Support was not forthcoming, with FO retorting that CGT was "burying its head in the sand" (FO Sevelnord Communiqué). A plant agreement, signed by CFE-CGC, FO and GSEA, provided a two-year pay freeze, working time extensions when daily production targets were not met and reduced notice periods in disbanding, creating or transferring production teams. In exchange, PSA pledged a three-year no redundancy policy. Refusing to sign, CGT maintained:

This agreement...could be applied to all of PSA, even the entire auto industry. We cannot accept such a dangerous agreement... They do not have the right to use the trauma of Aulnay to impose concessions at Sevelnord and say, 'first you sign then you get the vehicle'.

CGT PSA Delegate

Regarded by senior management as a pattern setter for the sector ${ }^{5}$, the Sevelnord agreement became generalised across PSA via the 2013 Nouveau contrat social (NCS). NCS provided a pay freeze for 2013 to 2016, daily production guarantees, mandatory job mobility and overtime, a near $50 \%$ reduction in overtime pay and limiting the summer break to three rather than four weeks. Plants producing fewer than 250,000 vehicles per year would also have one production line removed, with job losses as necessary. Prior to formal commencement of NCS negotiations, CGT proposed inter-confederal cooperation in company-wide strikes to protest PSA proposals. In the interim, CGT organised several one day strikes with subsequent CFDT participation (Table 4).

\footnotetext{
${ }^{5}$ See 'Peugeot urges broader pay deal after Sevelnord win', Reuters, 2012.
} 
Table 4

Aside from CFDT participation, CGT calls for wider union involvement went unanswered, apart from CFTC, publically announcing it would not partake as "we do not want to relive the CGT experience at Aulnay and send employees to the job centre...after making them think it was possible to stop the site from closing by fighting" (CFTC PSA Communiqué). CFE-CGC, CFTC, FO and GSEA combined to ratify NCS in exchange for PSA pledges to maintain production levels, avoid closures until 2016 and launch new models in each plant. Their signatures were criticised by CGT and CFDT, the latter, it appears, under pressure from plant sections. CGT maintained that promises on volumes were too low, essentially "hot air to justify regressive attacks" (CGT Poissy Delegate). In response, reformists maintained for example:

There are concessions to make. We don't want to become a second Aulnay. Other unions burnt tyres and intimidated employees, but in the end, did Aulnay stay open?

GSEA Tremery Section Leader

\section{PSA Plant Level}

Transposing NCS to plants required further consultation to tailor with each site's circumstance around working time in particular. The context of union site representativeness in this period is detailed below.

Table 5 
Patterns of reformist alliance and CGT independence replicates at three plants. The alliances' stated objectives were to develop "partnership unionism" (Sochaux Alliance), "pragmatic cooperation with management" (Mulhouse Alliance) and "preservation of the site and repatriation of production" (Rennes Alliance). Voting pacts, formed for CE elections, exhibited an anti-CGT stance, evident in circulated communiqués in the plants:

Why make a communal electoral list? Because our ideas on how to defend employees' interests are close: we think negotiation is always the best way. It's through working to draft and sign agreements that we find solutions...It is more effective than other scattered action which can play into management's hands. Certain unions will propose other ways of doing this, but history shows us (take Aulnay, for example) that resorting to violence does not always have the effect that employees expect.

Rennes Alliance Communiqué

Indeed, the Rennes Alliance emerged in the context of an unexpected surge in CGT votes in 2010 as the plant, based in the Catholic Breton region, is traditionally reformist. The surge was regarded by the Alliance as a 'protest vote' against job loss. Some evidence indicates PSA preference for these reformist alliances, insofar as it weakens CGT influence on plants' CEs. At Mulhouse for example, leaked management documents indicated a view that the alliance was "the best option" in the face of CGT's "reactionary communism". Yet alternative inter-union relations prevailed at plants where one dominant union commanded representative clout to independently determine outcomes: FO Poissy and GSEA Trémery. This limited the necessity for coalitions, although CGT attempted an alliance with SUD and CFDT to counter GSEA dominance at Trémery. This disbanded within a year over divisions on pay demands. 
In opposition to NCS negotiations, these plants saw, independent of company oneday strikes, shorter stoppages of varying duration (typically one to three hours) led by CGT or co-led by CGT and CFDT (Table 6).

\section{Table 6}

Strikes continued during consultations, with smaller numbers of workers involved. Justifying such actions, a CGT delegate claimed:

There is no real dialogue, a few delegates can't change management's mind in a meeting. It's our collective force in the workshops that will make them stop being so arrogant and make them eat the NCS. As for thinking that a union can get production workers out of a sticky situation, we don't think it can happen through negotiation. Employees should learn to defend themselves. They should have confidence in their own power, whether they are unionised or not unionised. Our power is in the number of workers we have, it's not about having a few dozen delegates. In reality, we can't negotiate anything with the boss, not without the exercise of power.

CGT Sochaux Section Leader

CGT coordinated stoppages to overlap NCS plant consultations. As a CGT Mulhouse delegate explained, stoppages were synchronised so "all employees will make themselves heard so that certain unions won't be tempted to agree with what management want". When CGT participated in consultations, it sought to thwart working time changes. Mixed success ensued. CGT Rennes and Sochaux blocked NCS holiday reductions when CFDT and delegates from signatory unions joined in support, an outcome apparently influenced by the fact consultations fell on the eve of elections with delegates seeking to avoid unpopular decisions. CGT Trémery, supported by SUD, failed to prevent the change in the absence of additional support, conspicuously from CFDT. Notably, CFDT central delegates advised CFDT Rennes 
and Sochaux to refrain from CGT collaboration in the build-up to 2014 elections. Falling in the months after the company agreement, these elections offer a reasonable proxy for measuring support for unions' NCS stance. The combined results, individually mixed across plants, saw CGT lose its position as PSA's leading representative union.

\section{Renault Company Level}

Renault's response to the 2008 recession was 4,000 redundancies, temporary unemployment and pay moderation (0\% in $2008-09,0.7 \%$ in 2010$)$. The Sandouville site risked closure, although the government maintained loans for Renault would only continue if the plant remained open. A tripartite-negotiated 2009 Contrat Social de Crise (CSC) at Renault provided for state supplemented 'partial unemployment' payments enabling employees to work fewer days, but retain $100 \%$ base pay rather than $50 \%$ under the state-only scheme. CFDT, CFE-CGC, CFTC and FO signed the agreement, whilst CGT refused, claiming payments were far from $100 \%$ of pay once annual leave and additional benefits were added. State support necessitated unions to offer quid pro quo however with government meetings with the unions pressing the need for labour reforms across plants. In this context, an alliance formed in 2010 between CGT, CFDT, CFE-CGC, CFTC and FO to prepare the ground for competitiveness negotiations, even though formal talks did not commence until 2012. Company representativeness in this period is outlined below.

\section{Table 7}

Prior to such negotiations, the alliance sought to coordinate bargaining in annual Renault pay rounds. For CGT, these proved disappointing. Whereas other unions 
sought $3.5 \%$ in 2011 , CGT sought $10 \%$ allied to campaigns of one-hour work stoppages ( $1.7 \%$ was ultimately secured). Opting to end cooperation with the alliance as a result, CGT argued pay outcomes "will essentially depend on the amount of mobilisations among employees" rather than inter-union negotiating demands (CGT Renault Communiqué). However, CGT returned to the alliance in 2012 under encouragement from CFDT with an agreed CGT-CFDT strategy of combining a 4.5\% pay demand with three one-day strikes across all plants (a position which led FO to withdraw from the alliance). Yet again, a split emerged with the final offer of $3 \%$ : CFECGC, CFTC and FO accepted, while CGT and CFDT sustained strike action and overtime bans in protest. Action continued across plants for one month postagreement, before CFDT withdrew, leaving CGT to call for stoppages which never occurred. Nonetheless, CGT developed better relations with CFDT in this period as competitiveness negotiations commenced in late 2012 and continued throughout early 2013. CGT Renault praised a CFDT booklet Renault En Danger in a memo to plant sections, detailing a convergence of views on reforming job design and emphasising quality rather than cost-focused production in car plants. As competitiveness negotiations proceeded and Renault sought 8,500 job losses and forced redeployment in its final terms, CGT attempted to revive the alliance. CGT proposed:

Given what is at stake, we think it necessary to organise a unified call to action. This would help our respective unions to organise collective action at local-level and allow for a larger level of mobilisation....with a view to making management take employees' demands into account. We invite you to join us.

CGT Renault Inter-Union Communiqué

The call went unheeded until later negotiation rounds when Renault threatened plant closures at Douai and Flins to secure the talks' conclusion. Denouncing Renault's 
threat, a CGT, CFDT, FO company strike was called with 1,700 workers participating across eight sites in January 2012. Two further strikes followed (Table 8). However, within weeks, CFE-CGC indicated its intention to sign and management concessions removing references to forced redeployment and a guarantee of sufficient production volumes led FO and CFDT to follow suit.

\section{Table 8}

The Contract for a New Dynamic of Renault Growth in France saw management pledge production of 710,000 vehicles by 2016 (520,000 vehicles were produced in 2012) and avoid closures until 2016. In return, unions agreed to 7,500 job losses through attrition, redeployment and early retirement between 2013 and 2016 as well as working time increases from 32 hours to an average of 35 hours per week and a one-year pay pause with a provision that future increases benchmark to German and Spanish auto plants (subsequently $0.5 \%, 2014,0.75 \% 2015$ ). CGT, refusing to sign, argued:

By saying "accept the lowest social bid and I will guarantee what I have already given you", management are instigating that, every time models change, another agreement will be needed asking employees to accept further concessions.

CGT Renault Delegate

\section{Renault Plant Level}

Transposing the Contract locally entailed further plant consultation on site specific matters. Representativeness in these plants is detailed below. 


\section{Table 9}

Reflecting company trends, an alliance involving CGT formed at Batilly, Cléon, Flins and Sandouville in 2010/2011. While Flins' alliance dissolved as early as 2011 due to CE elections, remaining alliances did not survive the Contract. At Batilly, the Contract split unions into a pro-agreement faction of CFDT and CFE-CGC, and an antiagreement alliance of CGT, SUD and an unusually militant CFTC section. The Contract also ended the alliance at Cléon involving CGT, CFDT and FO, and at Sandouville, involving CGT and FO. No inter-union cooperation formed at Le Mans, with CGT acting independently. This site proved the most strike-prone during competitiveness talks, with CGT organising nine strikes in the plant over the four months of negotiations with small numbers participating (Table 10). CGT Douai was weakened by a split in 2009 and was unrepresentative in the period studied ${ }^{6}$.

Table 10

CGT at Batilly, Cleon, Flins and Sandouville deployed a combination of legal injunction and CE/Comité d'hygiène, de sécurité et des conditions de travail (CHSCT) ${ }^{7}$ rights to obstruct consultations. Short CGT-led workplace stoppages also occurred despite opposition from other unions:

CGT still think that a negotiation cannot be done without blockading factories or protesting on the street. It's easier to never sign and to oppose everything because you can avoid taking responsibility.

CFE-CGC Cléon Section Leader

\footnotetext{
${ }^{6}$ Relating to divisions over adhering to CGT-FTM positions.

${ }^{7}$ Health, safety and working conditions committees
} 
When CGT says it wants to preserve jobs, it must accept this responsibility. It has found a comfortable place far away from meetings, occupying the media landscape outside of the factory. Unfortunately for them, decisions are not made in this way.

CFDT Sandouville Section Leader

The CGT, SUD, CFTC Batilly alliance combined stoppages with a legal case challenging the Contract's "automatic application" provision to the plant, as the site is technically a Renault subsidiary, Renault SoVAB (Société de Véhicules Automobiles de Batilly). Although first rejected in Court, the alliance won on appeal, before a further Renault challenge overturned the ruling. In the interim, management announced that Batilly's budget would be suspended and production of the site's main model transferred to Barcelona if the case blocked Contract changes. Deploying CE rights in response, CGT, SUD, CFTC had the threatened transfer independently costed which concluded that savings would be inferior to continued Batilly production. The alliance dismissed the threat's credibility.

CGT unsuccessfully pursued legal challenges at Cléon, Le Mans and Sandouville. These challenges claimed the Contract derogated from a 1999 agreement on working time at the plants. Unless this agreement was repealed, CGT maintained that the Contract could not override its terms. Their challenge was opposed by other unions, claiming obstruction risked the volumes promised under the agreement. Despite the claims' failure in court, CGT Cléon and Sandouville, utilising CHSCT rights, delayed the transposition of new working time arrangements by securing an independent assessment of shift impacts on employee safety. While the final report found no grounds to obstruct extension, the review delayed the introduction of revised shifts by 
four months. This was regarded as a "small victory for employees" by CGT Cléon. Parallel efforts at Le Mans to use CHSCT rights were prevented by CFE-CGC and CFDT voting the CGT resolution down. CE elections following this period again provide a reasonable proxy for gauging employee support for CGT strategy vis-à-vis the Contract. In a wider context of very minor loss at company level, plants observed mixed support for CGT action (Table 9).

\section{Discussion}

Literature on French trade unionism under decentralised bargaining discerns two contrasting trajectories. The first proposes that workplace bargaining exposes weak unions to firms' competitive pressures, inculcating subordinated compliance, while a second emphasises prospects for sustained militant opposition. While the prevalence of militant opposition among CGT sections in the case study complements the latter interpretation, some qualified elaboration is needed. While cultural traditions are relevant, the findings suggest institutional factors of bargaining structure, reformist union behaviour and electoral competition are equally important in explaining the militant opposition observed.

As discussed earlier, those adhering to militant orientations are inclined to oppose and/or limit the granting of concessions. However, strategic choices of this sort require sufficient resources to be effective. When militants lack resources in sufficient amounts to prevent 'give-backs', the second-best option is to withhold legitimacy from the concessionary process. This is relatively costless to pursue because company bargaining structure and reformist union behaviour provide the necessary 'opportunity structure' (Meyer, 2004). Concessions employers seek are likely to be negotiated with 
and ratified by reformist unions, rendering radical involvement superfluous, so long as the latter lack power to block agreements. Once reformists have sufficient representative powers to ratify agreements, militants can defect without pressure from employers, free from the constraints of unpalatable concessions. Thus, the causal links between coercive markets and ideological disorientation of unions noted elsewhere (Hyman, 2001; Murray et al. 2010) are not tightly coupled in the French case given bargaining structure and the multiplicity of reformist unions. These provide sufficient slack for radicals to retain militant opposition at workplace level.

If bargaining structure and reformist willingness to sign agreements enable militant opposition, electoral competition may actively encourage it. Of course, the political science literature on deradicalisation emphasises that when militants run in elections, they convert into vote maximisers, ideologically shifting to the centre to expand appeal (Tezcür, 2010). Given the 2008 reform tying bargaining capacity to workplace electoral representativeness, moderation of the militant tendency might have been expected to maximise voter appeal. Yet there is little evidence of this in the case study. Given that the moderate ground is already well occupied in the electoral contest, there is little advantage gained by militants moving into a crowded marketplace, potentially losing distinctiveness vis-à-vis other unions. Militants may calculate that dissatisfaction with reformist concessions will allow those standing outside agreements to grow electorally. Indeed, CGT electoral campaigning in the cases emphasised inter-union difference, portraying reformists as "house unions" complicit in negotiating "anti-social regressions". The hope is that militant populism may trump reformist cooperation. Discontent might manifest as protest votes, boosting militants' representativeness as observed at some individual plants. Indeed, reformists appear alive to this prospect, 
regularly justifying their own position by comparing it to the alleged futility of CGT militancy. The fact that militants retain the capacity to appeal to a (declining) constituency of hardcore support suggests representativeness is reasonably assured. Pressures to revise orientation and action may therefore be stymied in the short term.

What are the implications of this choice pattern for radical relations with employers, other unions and employees? In the case studies, militant opposition appears limited in its capacity to impose costs on employers. Legalistic obstruction may only delay and risks being thwarted by reformists, while strike numbers frequently rely on modest participation rates. While it is conceivable that small numbers of small strikes cause sizeable disruption in lean auto plants (Silver, 2003), militant opposition has not impacted on the calibre of agreements being struck, and the few successes evident in transposition relied on reformists' electoral opportunism. Interestingly, where militant opposition has notable effect is indirectly shaping reformist inter-union collaboration. As historically the most individually representative union in the industry, CGT has traditionally co-existed alongside a multiplicity of smaller reformist unions. The latter have overcome problems of size and fragmentation through collaboration, combining in sufficient numbers to support agreements. While this may simply be a 'numbers game' whereby reformists collaborate to reach requisite thresholds for signing agreements, there is an ideological convergence in favouring so-called 'responsible alliances' against the alleged recklessness of CGT militancy. This suggests a narrowing of the 'permissive ideational space' for militant action. Indeed, reformist inter-union behaviour more closely approximates the thesis of weakened unions succumbing to employer's competitive pressures. A growing delegitimisation of militant opposition in the face 
of job loss and plant closure is evident in majoritarian support amongst auto workers for reformist unions. Requiring $50 \%$ to ratify agreements, the 2016 El-Khomri reform may further consolidate inter-reformist collaboration, with the potential for further isolation of CGT.

Although radicals might judge the electoral payoffs from militant opposition superior to that of moderation, vacating the space of compromise in a context of high job insecurity may limit appeal beyond a narrowing constituency. Certainly, this is the aggregate pattern of results in the case study and there is evidence of replication elsewhere. Recent restructuring at Air France, for example, highlights similar trends where a three-year business plan implemented in 2012 heralded several rounds of voluntary redundancies for cabin crew and ground staff. While reformist unions gave support to the plans resulting in 5,000 job losses, CGT initiated several rounds of strikes, notoriously culminating in internationally reported physical attacks on company directors. Yet support for CGT in this period evidenced decline, with the union falling from first to fourth in Air France's electoral representativeness behind CFE-CGC, FO and UNSA. As noted previously, such electoral problems are reflected nationally with CFDT surpassing CGT as the country's largest union in 2017. Such trends appear to recall Boxall's (2008) argument that ineffectual choices lead to "strategic drift". Militant opposition may fail to change employers' positions when undermined by reformists, but may also miscalculate workers' preferences when faced with restructuring and job insecurity. 
In sum, the general conclusions to be inferred from this study is that coercive market forces at workplace level do not necessarily induce a shift from militant opposition among radical unions. The capacity for pursuing an independent agenda here is not attributable to internal power resources (Lévesque and Murray, 2005: 509), but externally derived from bargaining structure and the supply of reformist unionism to take up the slack. Competitive elections for workplace representativeness may reinforce militant opposition to ensure distinctiveness in a crowded electoral contest. Yet under conditions of restructuring and job insecurity, this risks strategic drift as militant opposition fails to alter employers' positions, is circumvented by rival unions acting in alliance and holds declining appeal amongst large sections of the workforce demographic. Further research might examine cases where radicals hold the 'balance of power' and their support is necessary for agreement ratification. In this case, pressures from coercive market forces on militant unionism may be more tightly coupled for radicals' capacity to vacate the concessionary space becomes difficult to accomplish. A break from the pattern of militant opposition might be expected. Research could also establish the consequences of such scenarios for inter-union relations and electoral support.

\section{References}

Andolfatto D. (2007) 'Les héritiers du mouvement ouvrier', in D. Andolfatto (ed.), Les Syndicats en France, La Documentation Française.

Bacon, P. and Blyton, P. (2004) 'Trade union responses to workplace restructuring: exploring union orientations and actions', Work, Employment and Society, 18:749773. 
Benson J. and Gospel H. (2008) ‘The emergent enterprise union', International Journal of Human Resource Management, 19:1367-1384.

Blyton, P. et al. (2001) 'Globalization and trade union strategy: industrial restructuring and human resource management in the international civil aviation industry', International Journal of Human Resource Management,12:445-463.

Boxall, P. (2008) 'Trade union strategy', in P.Blyton et al. (eds.), The Sage Handbook of Industrial Relations, London: Sage.

Boxall, P. and Haynes, P. (1997) 'Strategy and trade union effectiveness in a neoliberal environment', British Journal of Industrial Relations,35:567-591.

Clegg, D. and van Wijnbergen, C. (2011) 'Welfare institutions and the mobilisation of consent', European Journal of Industrial Relations,17:333-348.

Connolly, H. (2014) 'Trade union radicalism in France', in H. Connolly et al.(eds.), Radical Unions in Europe and the Future of Collective Representation, Peter Lang.

Giraud B. (2015) 'Negotiating under constraint: CGT representatives' appropriation of their role as a 'Social Partner', Relations Industrielles,70:306-326. 
Goyer, M. and Hancké, B. (2004) 'Labour in French corporate governance: the missing link', in H. Gospel and A. Pendleton (eds.), Corporate Governance and Labour Management, Oxford University Press.

Howell, C. (1992) Regulating Labor, Princeton University Press.

Howell, C. (2009) 'The transformation of French industrial relations', Politics \& Society, $37: 229-256$.

Hyman, R. (2001) Understanding European Trade Unionism, Sage.

Labbé, D. and Nezosi, G. (2007) 'Négociation collective, paritarisme et démocratie sociale', in D. Andolfatto (ed.), Les Syndicats en France, Documentation Française.

Laulom, S. (2012) 'The French system of employee representation at the enterprise', in R. Blanpain et al. (eds.), Systems of Employee Representation at the Enterprise, Kluwer Law International,51-71.

Lévesque, C. and Murray, G. (2005) 'Union involvement in workplace change', British Journal of Industrial Relations,43:489-514

Marginson, P. (2015) 'Coordinated bargaining in Europe: from incremental corrosion to frontal assault', European Journal of Industrial Relations,21:97-114.

Mathers, A. (2017) 'SUD: Social movement unionism and beyond’, Transfer,23:79-88. 
Meyer, (2004) 'Protest and political opportunities', Annual Review of Sociology,30:125-145.

Milner, S. (2002) 'France and the impossibility of partnership', S. Berger and H. Compston (eds.), Policy Concertation and Social partnership in Western Europe, Bergan.

Milner, S. (2012) 'Towards a European labour market? Trade unions and flexicurity in France and Britain', European Journal of Industrial Relations,18:219-234.

Milner, S. and Mathers, A. (2013) 'Membership, influence and voice: a discussion of trade union renewal in the French context', Industrial Relations Journal,44:122-138.

Ministère du Travail (2017) Nouvelle mesure d'audience de la représentativité syndicale, Paris.

Murray, G. et al. (2010) 'Referential unions and globalisation: a comparative study of workplace union dynamics',European Journal of Industrial Relations, 16:311-332.

National Institute of Statistics and Economic Studies (2014) The Manufacturing Industry in France since 2008, Insee.

Parsons, N. (2005) French Industrial Relations in the New World Economy, Routledge. 
Parsons, N. (2013a) 'Legitimizing illegal protest: the permissive ideational environment and 'bossnappings' in France', British Journal of Industrial Relations,51:288-309.

Parsons, N. (2013b) 'France', in C. Frege and J. Kelly (eds.), Comparative Employment Relations in the Global Economy, Routledge.

Parsons, N. (2015) 'Left parties and trade unions in France', French Politics,13:63-83.

Pernot J.M. (2010) Syndicats: Lendemains de crise? Gallimard.

Rogers, J. and Streeck, W. (1995) 'The study of works councils: concepts and problems', in J. Rogers and W. Streeck (eds.),Works Councils, Chicago University Press.

Silver, B. (2003) Forces of Labor, Cambridge University Press.

Strauss, A.L. (1987) Qualitative Analysis for Social Scientists, Cambridge University Press.

Streeck, W. (1984) Industrial Relations in West Germany, Heinemann.

Tezcür, G.M. (2010) 'The Moderation theory revisited: the case of Islamic political actors', Party Politics, 16:69-88. 
Thomas, A. (2013) 'Towards the managerialisation of trade unions? Recent trends in France and Germany', European Journal of Industrial Relations,19:21-36.

Tissandier, H. (2013) 'Difficult 50th congress for union confederation', European Observatory of Working Life[www.eurofound.europa.eu]

Upchurch, M., Taylor, G. and Mathers, A. (2009) The Crisis of Social Democratic Trade Unionism in Western Europe, Ashgate. 
Table 1 Case Study

\begin{tabular}{|c|c|c|c|}
\hline & Plant type/numbers employed (as of 2017) & $\begin{array}{l}\text { Redundancies and headcount loss (2008-2015) } \\
\text { (incl. early retirement, wastage, redeployment, } \\
\text { redundancy) }\end{array}$ & $\begin{array}{l}\text { Plants threatened with investment and model } \\
\text { loss/outsourcing/closure* }\end{array}$ \\
\hline PSA & $\begin{array}{l}11 \text { manufacturing/5 R\&D sites (France) } \\
\text { State share ownership taken in 2015: 13\% }\end{array}$ & 19,500 headcount reductions announced & \\
\hline Mulhouse & $\begin{array}{l}\text { Assembly } \\
7,500 \text { employees }\end{array}$ & 2,000 redundancies & $\begin{array}{l}\text { Threatened with closure and transfer of track line } \\
\text { to Slovakia (2012) }\end{array}$ \\
\hline Poissy & $\begin{array}{l}\text { Assembly } \\
5,800 \text { employees }\end{array}$ & 1500 redundancies & $\begin{array}{l}\text { Offer to increase future models to site if costs } \\
\text { compare favourably with Eastern European sites } \\
\text { (2015) }\end{array}$ \\
\hline Rennes & $\begin{array}{c}\text { Assembly } \\
4,000 \text { employees }\end{array}$ & 2000 redundancies & $\begin{array}{l}\text { Threat of model loss to either China, India or } \\
\text { Russia if 'variable night shift' not introduced } \\
\text { (2011) } \\
\text { Threatened with closure (2012) }\end{array}$ \\
\hline Sevelnord & $\begin{array}{l}\text { Assembly } \\
2,400 \text { employees }\end{array}$ & 350 redundancies & $\begin{array}{l}\text { Threatened with model loss to Spain, potential } \\
\text { closure (2012) }\end{array}$ \\
\hline Sochaux & $\begin{array}{l}\text { Assembly } \\
9,600 \text { employees }\end{array}$ & 2000 redundancies & $\begin{array}{l}\text { Threatening outsourcing of component } \\
\text { manufacture }\end{array}$ \\
\hline Trémery & $\begin{array}{l}\text { Powertrain manufacture } \\
5,000 \text { employees }\end{array}$ & 800 redundancies & \\
\hline Renault & $\begin{array}{l}10 \text { manufacturing/2 R\&D sites (France) } \\
\text { State owned shares: } 19 \% \text { (increased from } 15 \% \text { in 2015) }\end{array}$ & 12,500 headcount reductions announced & \\
\hline Batilly & $\begin{array}{c}\text { Assembly } \\
2,300 \text { employees }\end{array}$ & 400 redundancies & $\begin{array}{l}\text { Threatened with re-allocation of two models to } \\
\text { Spain and Russia (2013) }\end{array}$ \\
\hline Clēon & $\begin{array}{l}\text { Powertrain manufacture } \\
3,550 \text { employees }\end{array}$ & 600 redundancies & $\begin{array}{l}\text { Product and process engineering roles } \\
\text { threatened with outsourcing (2013) }\end{array}$ \\
\hline Douai & $\begin{array}{l}\text { Assembly } \\
3,800 \text { employees }\end{array}$ & 600 redundancies & Threatened with closure (2013) \\
\hline Flins & $\begin{array}{l}\text { Assembly } \\
2,190 \text { employees }\end{array}$ & 400 redundancies & $\begin{array}{l}\text { Threatened with closure and transfer of } \\
\text { production to Turkey (2013) }\end{array}$ \\
\hline Le Mans & $\begin{array}{l}\text { Powertrain manufacture } \\
2,380 \text { employees }\end{array}$ & 740 redundancies & $\begin{array}{l}\text { Site compared with sites in Villeurbane and Spain } \\
\text { for securing investment (2012) }\end{array}$ \\
\hline Sandouville & $\begin{array}{l}\text { Assembly } \\
1,770 \text { employees }\end{array}$ & 1000 redundancies & $\begin{array}{l}\text { Threatened with closure (2008) } \\
\text { Review of maintenance department to identify } \\
\text { non-core for outsourcing (2013) }\end{array}$ \\
\hline
\end{tabular}


Table 2 Evidence and Analysis

\begin{tabular}{|c|c|c|}
\hline Source & Type & \multirow{5}{*}{$\begin{array}{l}\text { Analysis } \\
\text { Evidence coded into categories of 'orientation' } \\
\text { (patterns of militancy/moderation) and 'action' } \\
\text { (patterns of conflict/cooperation) } \\
\text { Evidence to measure support for CGT using CE } \\
\text { results and numbers participating in CGT } \\
\text { strikes (where available) }\end{array}$} \\
\hline Documents & $\begin{array}{c}1200 \text { CGT memoranda } \\
\text { PSA/Renault CE minutes } \\
700 \text { CFDT, CFE-CGC, CFTC, FO } \\
\text { PSA/Renault memoranda }\end{array}$ & \\
\hline \multirow[t]{2}{*}{ Interviews } & $\begin{array}{c}\text { Semi-structured interviews: } 16 \text { CGT } \\
\text { PSA/Renault section leaders from Table } 1 \\
\text { sites }\end{array}$ & \\
\hline & $\begin{array}{c}\text { Semi-structured interviews: } 31 \text { CFDT, CFE- } \\
\text { CGC, CFTC, FO, Le Groupement des } \\
\text { Syndicats Européens de l'Automobile } \\
\left(\text { GSEA }^{8}\right) \text { PSA/Renault section leaders from } \\
\text { Table } 1 \text { sites }\end{array}$ & \\
\hline Observation & CGT strikes at PSA/Renault sites & \\
\hline
\end{tabular}

\footnotetext{
8 GSEA: Groupement des syndicats européens de l'automobile (Association of European Automobile Unions) is a small association of trade unions established almost exclusively in PSA. Historically, GSEA originates from the 'yellow union movement' (syndicalisme jaune), notably Confédération des syndicats libres (CSL) and Confédération française du travail (CFT). GSEA is representative within PSA, but its influence in other companies is marginal. It is also active in PSA Vigo, Spain.
} 
Table 3 PSA Representativeness (\%)

\begin{tabular}{|l|l|l|l|l|l|l|}
\hline & CGT & CFDT & CFE-CGC & CFTC & FO & 18 \\
\hline 2011 & 22 & 14 & 18 & 12 & 12 & 12 \\
\hline 2015 & 20 & 15 & 20 & 12 & 20 \\
\hline
\end{tabular}


Table 4 Company-Wide Strikes Protesting PSA NCS Proposals

\begin{tabular}{|l|c|c|}
\hline & Frequency & $\begin{array}{c}\text { Total Workers } \\
\text { Involved }\end{array}$ \\
\hline CGT Action & 3 & 4200 \\
\hline CGT Joint Action & 3 & 4000 \\
\hline
\end{tabular}

Source: Union documentation 
Table 5 PSA Plant-Level Representativeness (\%)

\begin{tabular}{|c|c|c|c|c|c|c|c|c|c|}
\hline & CGT & CFDT & CFE-CGC & CFTC & FO & GSEA & SUD & UNSA & $\begin{array}{c}\text { Formal Inter-Union } \\
\text { Alliance }\end{array}$ \\
\hline \multicolumn{10}{|l|}{ Mulhouse } \\
\hline $2007^{*}$ & 25 & 19 & \multirow{3}{*}{\multicolumn{3}{|c|}{$\begin{array}{c}\text { Alliance } \\
\text { CFE-CGC/CFTC/FO }\end{array}$}} & & & & 54 \\
\hline 2011 & 25 & 20 & & & & & 1 & 3 & 51 \\
\hline 2015 & 22 & 20 & & & & & & 4 & 54 \\
\hline \multicolumn{10}{|l|}{ Poissy } \\
\hline 2009 & 27 & 4 & 11 & 13 & 41 & & 4 & & \\
\hline 2013 & 27 & 1 & 8 & 14 & 44 & & 6 & & \\
\hline \multicolumn{10}{|l|}{ Rennes } \\
\hline $2006^{*}$ & 21 & 8 & 8 & & 11 & 46 & & & \\
\hline 2010 & 35 & 8 & 7 & 4 & 15 & 32 & & & \\
\hline 2014 & 23 & 25 & \multicolumn{4}{|c|}{$\begin{array}{c}\text { Alliance } \\
\text { CFE-CGC/CFTC/FO/GSEA }\end{array}$} & & & 53 \\
\hline \multicolumn{10}{|l|}{ Sevelnord } \\
\hline $2005^{*}$ & 25 & 8 & 5 & & 16 & 28 & & & \\
\hline 2009 & 27 & 7 & 7 & 8 & 20 & 27 & & 5 & \\
\hline 2013 & 26 & 10 & 6 & 4 & 25 & 28 & & 1 & \\
\hline \multicolumn{10}{|l|}{ Sochaux } \\
\hline $2007^{*}$ & 30 & 10 & \multirow{3}{*}{\multicolumn{4}{|c|}{$\begin{array}{c}\text { Alliance } \\
\text { CFE-CGC/CFTC/FO/GSEA }\end{array}$}} & & & 60 \\
\hline 2011 & 35 & 12 & & & & & & & 53 \\
\hline 2015 & 31 & 14 & & & & & & & 55 \\
\hline \multicolumn{10}{|l|}{ Trémery } \\
\hline 2010 & 15 & 20 & 3 & 13 & 3 & 35 & 11 & & \\
\hline 2014 & 21 & 10 & 4 & 13 & 2 & 40 & 10 & & \\
\hline
\end{tabular}


Table 6 Plant Strikes Protesting PSA NCS Proposals and Plant Transposition*

\begin{tabular}{|c|c|c|c|c|}
\hline & \multicolumn{2}{|c|}{ Company Negotiations } & \multicolumn{2}{|c|}{ Plant Transposition } \\
\hline & Frequency & $\begin{array}{c}\text { Total Workers } \\
\text { Involved }\end{array}$ & Frequency & $\begin{array}{l}\text { Workers } \\
\text { Involved }\end{array}$ \\
\hline \multicolumn{5}{|l|}{ Mulhouse } \\
\hline CGT Action & & & 1 & 30 \\
\hline CGT Joint Action & 2 & 1100 & & \\
\hline \multicolumn{5}{|l|}{ Poissy } \\
\hline CGT Action & 1 & 350 & 1 & 15 \\
\hline \multicolumn{5}{|l|}{ CGT Joint Action } \\
\hline \multicolumn{5}{|l|}{ Rennes } \\
\hline CGT Action & 2 & & 10 & 180 \\
\hline CGT Joint Action & 4 & 3250 & 1 & 800 \\
\hline \multicolumn{5}{|l|}{ Sochaux } \\
\hline CGT Action & & & 2 & 330 \\
\hline CGT Joint Action & 2 & 1400 & & \\
\hline \multicolumn{5}{|l|}{ Trémery } \\
\hline \multicolumn{5}{|l|}{ CGT Action } \\
\hline CGT Joint Action & 1 & & 1 & \\
\hline
\end{tabular}


Table 7 Renault Representativeness (\%)

\begin{tabular}{|l|c|c|c|c|c|c|}
\hline & CGT & CFDT & CFE-CGC & CFTC & 5 & FO \\
\hline 2011 & 25 & 19 & 30 & 5 & 16 \\
\hline 2015 & 24 & 21 & 32 & 2 & 13 \\
\hline
\end{tabular}




\section{Table 8 Company-wide strikes protesting Renault Contract proposals}

\begin{tabular}{|l|c|c|}
\hline & Frequency & $\begin{array}{c}\text { Total Workers } \\
\text { Involved }\end{array}$ \\
\hline CGT Action & 1 & 700 \\
\hline CGT Joint Action & 3 & 3000 \\
\hline
\end{tabular}

Source: Union documentation 
Table 9 Renault Plant Level Representativeness (\%)

\begin{tabular}{|c|c|c|c|c|c|c|c|c|}
\hline & CGT & CFDT & CFE-CGC & CFTC & FO & SUD & UNSA & $\begin{array}{l}\text { Formal Inter- } \\
\text { Union Alliance }\end{array}$ \\
\hline \multicolumn{9}{|l|}{ Batilly } \\
\hline $2007^{*}$ & 37 & 9 & 12 & 13 & 17 & 12 & & \\
\hline 2011 & 32 & 11 & 10 & 16 & 13 & 17 & & \\
\hline \multicolumn{9}{|l|}{ Cléon } \\
\hline $2005 *$ & 44 & 17 & 23 & 5 & 10 & & & \\
\hline 2009 & 49 & 15 & 24 & & 12 & & & \\
\hline 2013 & 52 & 15 & 24 & & & & 9 & \\
\hline \multicolumn{9}{|l|}{ Douai } \\
\hline $2006^{*}$ & 28 & 22 & 8 & 5 & 37 & & & \\
\hline 2010 & $\begin{array}{c}9 \text { (CGT-Douai)/6 } \\
\text { (Confederal } \\
\text { CGT)** }\end{array}$ & 18 & 11 & 6 & 29 & 21 & & \\
\hline 2014 & 12 & 19 & 17 & 1 & 30 & 21 & & \\
\hline \multicolumn{9}{|l|}{ Flins } \\
\hline $2007 *$ & 23 & 10 & 12 & 3 & 52 & & & \\
\hline 2011 & 31 & 15 & 14 & 2 & 38 & & & \\
\hline 2015 & 26 & 30 & 14 & & 21 & & 10 & \\
\hline \multicolumn{9}{|c|}{ Le Mans } \\
\hline 2014 & 40 & 24 & 36 & & & & & \\
\hline \multicolumn{9}{|c|}{ Sandouville } \\
\hline $2006^{*}$ & 46 & 3 & $\begin{array}{c}\text { Alliance } \\
\text { CFE-CGC/FO }\end{array}$ & & $\begin{array}{c}\text { Alliance } \\
\text { CFE-CGC/FO }\end{array}$ & & & 50 \\
\hline 2010 & 50 & $x$ & 12 & & 38 & & & \\
\hline 2014 & 35 & 7 & $\begin{array}{c}\text { Alliance } \\
\text { CFE-CGC/FO }\end{array}$ & & $\begin{array}{c}\text { Alliance } \\
\text { CFE-CGC/FO }\end{array}$ & & & 58 \\
\hline
\end{tabular}

*Pre-representative reform results where available. Average turnout: $80 \%$. ${ }^{* *}$ CGT-Douai section split into rival groups both claiming rights to CGT title. Source: Election Reports. 
Table 10 Plant Strikes Protesting Renault Contract Proposals and Plant Transposition*

\begin{tabular}{|c|c|c|c|c|}
\hline & \multicolumn{2}{|c|}{ Company Negotiations } & \multicolumn{2}{|c|}{ Plant Transposition } \\
\hline & Frequency & $\begin{array}{c}\text { Total Workers } \\
\text { Involved }\end{array}$ & Frequency & $\begin{array}{l}\text { Workers } \\
\text { Involved }\end{array}$ \\
\hline \multicolumn{5}{|l|}{ Batilly } \\
\hline CGT Joint Action & 1 & 103 & 5 & \\
\hline \multicolumn{5}{|l|}{ Cléon } \\
\hline CGT Action & & & 1 & 80 \\
\hline CGT Joint Action & 3 & 405 & & \\
\hline \multicolumn{5}{|l|}{ Douai } \\
\hline \multicolumn{5}{|l|}{ CGT Action } \\
\hline CGT Joint Action & 1 & 26 & 2 & \\
\hline CGT Joint Action & 2 & 385 & & \\
\hline \multicolumn{5}{|l|}{ Le Mans } \\
\hline CGT Action & 9 & 190 & & \\
\hline CGT Joint Action & 1 & & & \\
\hline \multicolumn{5}{|l|}{ Sandouville } \\
\hline CGT Action & & & 1 & 100 \\
\hline CGT Joint Action & 2 & 275 & & \\
\hline
\end{tabular}


